\title{
Management efficiency and profitability: A Case study of Petrochemical Industry
}

\author{
Bhagabata Behera $^{1}$ and Abhijit Das ${ }^{2}$
}

\author{
${ }^{1}$ Assistant Professor in Commerce \\ Ravenshaw University, Cuttack, Orissa, India \\ ${ }^{2}$ Research Scholar in Commerce \\ School of Commerce, Ravenshaw University, Cuttack, Orissa, India
}

\begin{abstract}
The ability of the firm to generate profit is popularly termed as Profitability. Profitability measures the effectiveness of the management in using its available resources to earn profit. The term 'profitability' is a relative one. The term 'profitability' leads to a common measurement of 'efficiency' of the business by different stakeholders. More will be the profitability, higher shall be its economic efficiency and the opposite is true when profitability is low (Eljelly A 2004). The paper is intended to study the profitability \& activity ratios and to examine how the profitability of a company gets changed by the managerial efficiency in general and petrochemical industry in particular.
\end{abstract}

Key words: Profitability ratio, Net profit Ratio (NPR), Activity ratio, Total assets turnover ratio (TATR)

\section{Introduction}

Whenever a business starts its operations, its main goal is to earn or maximize profits. A profit earning business can contribute positively towards society in terms of welfare activities or CSR. Owners or promoters take lot of hardship to stand their business by investing their monetary and physical resources. It is therefore the responsibility of the business to maximize their wealth. Wealth comes from profit hence in any case profit should be the ultimate aim of any business. Further, profit can be maximized when resources are invested in productive assets. Therefore it is crucial for the business managers to choose appropriate assets in line with the risk profile of the business. This means, the business should pursue in that area where the managers have experience in managing the affairs. Management of business uses the financial statements for assessing the efficiency of several decisions. The main goal of financial statements is to provide financial information about a firm's performance that helps to meet decision makers' desire for certain information. Financial statements provide financial data that need analysis, comparison and interpretation for taking decision both by the internal and external users of accounting information. Financial analysis aims at the facts and relationships related to managerial performance, operating efficiency, financial positions' strengths and weaknesses and goodwill of the company. The analytical techniques are of utmost important in management control system, helping the managers to take constant review of actual performance, to analyze the reasons for major deviations if any, which may help in corrective action wherever indicated. Financial manager uses the statements of profit and loss to analyze the operating result of a business concern for the whole accounting year. It considers all the expenses and incomes and thereby shows gross profit, operating profit and net profit or net loss of the business during the period. Financial analysis is basically related to profitability analysis. The performance of managers and the efficiency of the firm are measured through the profitability of the business (Eskandari, 2007). Thus the paper undertakes the study of management efficiency and how the profitability of a company gets changed by the managerial activity of 10 petrochemical companies.

\section{Review of literatures}

The literatures reviewed are narrated below.

Patel (2004) has made an attempt to examine the profitability of Colour - Chem Limited during 10 years period from1981 to 1999 . He had used multiple correlation coefficient technique was to 
analyze the joint the impact of net fixed assets, sales and net worth on profitability. It was from the analysis that sales and net fixed assets, sales and net worth, and net fixed assets and net worth had significant effect on net profit of the sample company under consideration. It was also revealed that the company was in a sound financial position. Manor Selvi and Vijayakumar (2007) attempted to examine the trends of rates of profit of selected Indian Automobile Industries over the period from 1991-2004. Further the measure of dispersion was calculated to find out the variations in the series of profit rates company wise. The declining trend of profitability was also found based on average growth rates during the study period. The study revealed adverse effect of various controls on prices, output, expansion and investment etc., exerted by government over time. Garcia-Teruel and Martinez-Solano (2007) conducted a study to the profitability of small and medium sized Spanish firms. Using panel data regression methodology, the authors revealed that managers can create value by reducing their inventories and the number of days for which their accounts are outstanding. The authors further concluded that SMEs have to be concerned with working capital management because they can also create value by reducing their cash conversion cycle to a minimum, as far as that is reasonable. Parikh (2012) studied 146 large as well as medium scale firms for their financial restructuring. The financial performances of these companies were studied through their financial statements. The parameters of financial performance such as sales, gross profits, net profits, gross assets, current ratio and taxes paid by them to the government, were considered for the analysis. Paired - $t$ - test had been used to compare before and after the restructuring. The analysis revealed that the significant impact of financial restructuring on gross profit of large and medium sized firms in the long run.

\section{Objectives}

Objectives in specific are:

1. To analyze the profitability of the sample petrochemical companies.

2. To study the activity ratio of the sample petrochemical companies.

3. To find out the relation between profitability and management efficiency

\section{Research Methodology}

The sample size, sampling techniques adopted, the data collection instruments employed and an overview of the methods or techniques used in data analysis have been presented in this section. The sample includes 10 randomly selected petrochemical companies as listed below. The annual reports of the sample companies have been collected from the company websites through secondary sources during 2013-2017.

Table-1: List of sample companies

\begin{tabular}{|c|c|}
\hline $\begin{array}{c}\text { Sl. } \\
\text { No. }\end{array}$ & Sample Companies \\
\hline 1 & C I L Nova Petrochemicals Ltd. \\
\hline 2 & $\begin{array}{c}\text { Deepak Fertilisers \& Petrochemicals Corpn. } \\
\text { Ltd. }\end{array}$ \\
\hline 3 & G A I L (India) Ltd. \\
\hline 4 & I G Petrochemicals Ltd. \\
\hline 5 & Mangalore Refinery \& Petrochemicals Ltd. \\
\hline 6 & Numaligarh Refinery Ltd. \\
\hline 7 & Oil \& Natural Gas Corpn. Ltd. \\
\hline 8 & Oswal Chemical \& fertilizers Ltd. \\
\hline 9 & Rashtriya Chemicals \& Fertilizers Ltd. \\
\hline 10 & Shiva Global Agro Inds. Ltd. \\
\hline
\end{tabular}

\section{Materials and Methods}

The research undertakes the descriptive statistics such as average, S.d and C.V to analyze the data. Regression analysis method has been employed to find the association between profitability and management efficiency by considering Net profit ratio (profitability ratio) and Total asset turnover ratio (Activity ratio).

\section{Profitability Ratio}

It refers to the analysis of profits in relation to some other variables of the business. That variable may be revenue from operations or assets employed in the business and the ratios calculated to meet this objective are known as profitability ratios. Profitability ratios are the ultimate measure through which both operating and financial performance can be gauged. Different profitability ratios serve different purposes. The paper undertakes the Net profit ratio for the analysis.

\section{Activity Ratios}

The activity ratios show the number of times the resources employed or for that purpose any constituent of assets is converted into sales during an accounting period. Activity ratio analysis gives an indication about the speed with which business processes are being performed. Total Assets Turnover Ratio is considered in the Analysis. 


\section{Net profit ratio (NPR)}

Net profit ratio is based on overall concept of profit. It is loosely termed as net profit margin. In other words, it shows the operating result of an enterprise. It takes both operating and non operating expenses and incomes of the business. It is calculated as (Net profit/Net sales) $\times 100$. In this case, net profit means profit after tax (PAT).

It is a measure of net profit margin in relation to operating revenue. It is mainly considered by shareholders as their return since it represents an amount after paying to all the stakeholders. It can be said as residual profit. Shareholders use it to compute return on equity which matters or urges shareholders to invest more in the business.

Total asset turnover ratio (TATR)

This ratio shows the sales generated out of investment in total asset. This ratio measures whether assets are utilized to their best possible ways or not. The ratio is very helpful in comparing the performance of asset utilization among different firms provided they are adjusted for depreciation and amortisation of assets over the period among the firms. It is calculated as:

Total asset turnover ratio $=$ Sales $/$ Total assets

\section{Multiple Regressions}

Multiple Regression analysis attempts to study the relationship between a dependent variable and a set of independent variables (one or more). It is a statistical technique that allows us to predict someone's score on one variable on the basis of their scores on several other variables.

\section{Descriptive Statistics of Net profit ratio}

Table -2: Net profit Ratio

\begin{tabular}{|c|c|c|c|c|c|c|c|c|}
\hline Company Name & Mar-13 & Mar-14 & Mar-15 & Mar-16 & Mar-17 & Average & S.D & C.V \\
\hline $\begin{array}{c}\text { C I L Nova } \\
\text { Petrochemicals } \\
\text { Ltd. }\end{array}$ & 0.85 & 0.84 & 1.54 & 2.79 & 2.22 & 1.648 & 0.856253 & 51.95713 \\
\hline $\begin{array}{c}\text { Deepak Fertilisers } \\
\text { \& Petrochemicals } \\
\text { Corpn. Ltd. }\end{array}$ & 5.18 & 5.99 & 1.99 & 2.05 & 4.39 & 3.92 & 1.8245 & 46.54337 \\
\hline $\begin{array}{c}\text { G A I L (India) } \\
\text { Ltd. }\end{array}$ & 8.34 & 6.97 & 4.96 & 3.81 & 7.08 & 6.232 & 1.816004 & 29.13998 \\
\hline $\begin{array}{c}\text { I G } \\
\text { Petrochemicals } \\
\text { Ltd. }\end{array}$ & 2.65 & 0.1 & 2.3 & 5.72 & 8.88 & 3.93 & 3.415802 & 86.91607 \\
\hline $\begin{array}{c}\text { Mangalore } \\
\text { Refinery \& } \\
\text { Petrochemicals } \\
\text { Ltd. }\end{array}$ & -1.19 & 0.66 & -2.8 & 2.5 & 3.42 & 0.518 & 2.564005 & 494.9816 \\
\hline $\begin{array}{c}\text { Numaligarh } \\
\text { Refinery Ltd. }\end{array}$ & 1.44 & 3.74 & 6.82 & 10 & 13.19 & 7.038 & 4.713875 & 66.97748 \\
\hline $\begin{array}{c}\text { Oil \& Natural Gas } \\
\text { Corpn. Ltd. }\end{array}$ & 21.22 & 21.77 & 18.32 & 19.07 & 16.04 & 19.284 & 2.314461 & 12.00198 \\
\hline $\begin{array}{c}\text { Oswal Chemical } \\
\text { \& fertilizers Ltd. }\end{array}$ & -7.25 & 50.05 & 38.04 & 25.6 & 44.39 & 30.166 & 22.80625 & 75.60251 \\
\hline $\begin{array}{c}\text { Rashtriya } \\
\text { Chemicals \& } \\
\text { Fertilizers Ltd. }\end{array}$ & 3.98 & 3.49 & 4.61 & 1.61 & 1.97 & 3.132 & 1.294071 & 41.31772 \\
\hline $\begin{array}{c}\text { Shiva Global Agro } \\
\text { Inds. Ltd. }\end{array}$ & 1.89 & 1.84 & 1.87 & 1.73 & 2.3 & 1.926 & 0.218014 & 11.31951 \\
\hline
\end{tabular}

Source: CIME report

Table-1 reveals that Net profit ratio of all most all the companies had shown fluctuating trend. But, C I L Nova Petrochemicals Ltd. I G Petrochemicals Ltd., Mangalore Refinery \& Petrochemicals Ltd., Numaligarh Refinery Ltd.,Oswal Greentech Ltd ,
Shiva Global Agro Inds. Ltd. and Oil \& Natural Gas Corpn. Ltd had shown fluctuating and upward trend. Oil \& Natural Gas Corpn. Ltd and Oswal Chemical \& fertilizers Ltd. have attained the maximum average Net profit ratio amongst all, 
reflecting their efficiency in manufacturing, administering and selling the products. Net profit ratio is considered as overall measure of the firm's ability to generate profit from sales. Though, I G Petrochemicals Ltd. had shown fluctuating and rising trend of net profit ratio, but the ratios had fluctuated at higher rate as clear from coefficient variation of $86.91607 \%$. Mangalore Refinery \&
Petrochemicals Ltd. had shown fluctuating trend of net profit ratio with C. V of $494 \%$. Deepak Fertilisers \& Petrochemicals Corpn. Ltd., G A I L (India) Ltd. and Rashtriya Chemicals \& Fertilizers Ltd. had shown fluctuating and declining trend of net profit ratio during the study period.

Descriptive Statistics of Net profit ratio

Table-3: Total asset turnover ratio

\begin{tabular}{|c|c|c|c|c|c|c|c|c|}
\hline Company Name & 13-Mar & 14-Mar & 15-Mar & 16-Mar & 17-Mar & Average & S.d & C.V \\
\hline $\begin{array}{l}\text { C I L Nova } \\
\text { Petrochemicals } \\
\text { Ltd. } \\
\end{array}$ & 1.837 & 1.80162 & 1.67116 & 1.43616 & 1.51214 & 1.6517 & 0.1756 & 10 \\
\hline $\begin{array}{l}\text { Deepak Fertilisers } \\
\text { \& Petrochemicals } \\
\text { Corpn. Ltd. }\end{array}$ & 0.93072 & 1.26786 & 1.12715 & 0.39461 & 0.44885 & 0.8338 & 0.3952 & 47 \\
\hline $\begin{array}{l}\text { G A I L (India) } \\
\text { Ltd. }\end{array}$ & 0.93938 & 1.02083 & 1.00786 & 0.90523 & 0.82165 & 0.9389 & 0.0811 & 8 \\
\hline $\begin{array}{l}\text { I G } \\
\text { Petrochemicals } \\
\text { Ltd. }\end{array}$ & 1.71477 & 1.72578 & 2.14530 & 1.79208 & 1.62624 & 1.8008 & 0.2014 & 11 \\
\hline $\begin{array}{l}\text { Mangalore } \\
\text { Refinery \& } \\
\text { Petrochemicals } \\
\text { Ltd. } \\
\end{array}$ & 2.57114 & 1.88542 & 1.7216 & 1.18323 & 1.80078 & 1.8324 & 0.4957 & 27 \\
\hline $\begin{array}{l}\text { Numaligarh } \\
\text { Refinery Ltd. }\end{array}$ & 1.93132 & 1.8287 & 1.5360 & 1.75646 & 1.87789 & 1.7864 & 0.1535 & 8 \\
\hline $\begin{array}{l}\text { Oil \& Natural Gas } \\
\text { Corpn. Ltd. }\end{array}$ & 0.38848 & 0.37141 & 0.36370 & 0.3105 & 0.27272 & 0.3417 & 0.0481 & 14 \\
\hline $\begin{array}{l}\text { Oswal Greentech } \\
\text { Ltd. }\end{array}$ & 0.01118 & & 0.00042 & 0.0177 & $3.42 \mathrm{E}-05$ & 0.0058 & 0.0080 & 138 \\
\hline $\begin{array}{l}\text { Rashtriya } \\
\text { Chemicals \& } \\
\text { Fertilizers Ltd. }\end{array}$ & 1.17640 & 1.18450 & 1.24744 & 0.47484 & 1.08478 & 1.0339 & 0.3176 & 30 \\
\hline $\begin{array}{l}\text { Shiva Global Agro } \\
\text { Inds. Ltd. }\end{array}$ & 0.92991 & 0.84681 & 1.00896 & 0.93481 & 0.82752 & 0.90960 & 0.0738 & 8 \\
\hline
\end{tabular}

Source: CIME report

The asset turnover ratio measures the value of a company's sales relative to the value of its asset. Total asset turnover ratio had shown a declining trend for a majority of the sample companies during the study period. I G Petrochemicals Ltd. and Mangalore Refinery \& Petrochemicals Ltd. recorded the maximum value and Oswal Chemical \& fertilizers Ltd. recorded the minimum value amongst all sample companies under study. It indicates that $I$ G Petrochemicals Ltd. and Mangalore Refinery \& Petrochemicals Ltd. are more efficient in using its assets to generate sales. But, Shiva Global Agro Inds. Ltd had maintained the ratio consistently in comparison to other companies as clear from low degree of C.V $8 \%$, And Oswal Greentech Ltd. marked inconsistent asset turnover ratio with C.V of $138 \%$.

\section{Regression analysis}

Further regression analysis is used to test the relation between profitability and management efficiency. The net profit ratio (NPR) is considered as dependent variable and total asset turnover ratio (TATR) is taken as independent variable. Here, the net profit ratio is used for profitability ratio and asset turnover ratio for efficiency ratio (Kothari, 2008). 
Table-4: Model Summary ${ }^{b}$

\begin{tabular}{|c|c|c|c|c|c|}
\hline Model & $\mathrm{R}$ & R Square & Adjusted R Square & $\begin{array}{l}\text { Std. Error of the } \\
\text { Estimate }\end{array}$ & Durbin-Watson \\
\hline 1 & $.545^{\mathrm{a}}$ & .0 .297 & .001 & 80.38937 & 2.052 \\
\hline \multicolumn{6}{|c|}{ a. Predictors: (Constant), TATR } \\
\hline \multicolumn{4}{|c|}{ b. Dependent Variable: NPR } & & \\
\hline
\end{tabular}

The multiple correlation coefficient $\mathrm{R}=0.545$ indicates that there is a average positive correlation between the Net Profit Margin (NPM) and the variables predicted by the regression model (TATR).

Table-5: Coefficients ${ }^{\mathrm{a}}$

\begin{tabular}{|c|c|c|c|c|c|c|}
\hline & & \multicolumn{2}{|c|}{ Unstandardized Coefficients } & \multirow{2}{*}{$\begin{array}{c}\begin{array}{c}\text { Standardized } \\
\text { Coefficients }\end{array} \\
\text { Beta } \\
\end{array}$} & \multirow[b]{2}{*}{$\mathrm{t}$} & \multirow[b]{2}{*}{ Sig. } \\
\hline \multicolumn{2}{|c|}{ Model } & B & Std. Error & & & \\
\hline \multirow[t]{2}{*}{1} & (Constant) & -43.109 & 33.758 & & -1.277 & .020 \\
\hline & TATR & 22.802 & 22.569 & .245 & 1.010 & .032 \\
\hline \multicolumn{4}{|c|}{ a. Dependent Variable: NPR } & & & \\
\hline
\end{tabular}

The $t$ and Sig (p) values give a rough indication of the impact of each predictor variable - a big absolute $t$ value and small $p$ value suggest that $a$ predictor variable having a large impact on the criterion variable. The standardized regression coefficients measure the change in the dependent variable in units of its standard deviation when the independent variable increases by one standard deviation. The unstandardized Beta Coefficients give a measure of the contribution of each variable to the model. A large value indicates that a unit change in this predictor variable has a large effect on the criterion variable while other predictors remain constant.

Unstandardized regression coefficients are used to estimate the regression line as follows:

$$
Y=-43.109+22.802 X_{1}
$$

It is clear from the regression equation that TATR is positively correlated to NPM. The higher value of-t (1.010) for TATR indicates the significant positive impact of TATR on NPM. The p-value is $0.032<0.05$, so it is accepted that there is significant relationship between NPR and TATR at $5 \%$ level of significance during 5 years study period.

\section{Results and Discussion}

Net profit ratio is considered as overall measure of the firm's ability to generate profit from sales. It is evident from the analysis that, net profit ratio of all most all the companies had shown fluctuating trend. But, Oil \& Natural Gas Corpn. Ltd and Oswal have attained the maximum average Net profit ratio amongst all. It reflects the efficiency of Oil \& Natural Gas Corpn. Ltd and Oswal in manufacturing, administering and selling the products. I G Petrochemicals Ltd. and Mangalore Refinery \& Petrochemicals Ltd. recorded the maximum value of TATR and Oswal Greentech Ltd. recorded the minimum value amongst all sample companies under study. It indicates that I G Petrochemicals Ltd. and Mangalore Refinery \& Petrochemicals Ltd. are more efficient in using its assets to generate sales. Multiple regression analysis exhibited that TATR is positively correlated to NPM. There is significant relationship between NPR and TATR at 5\% level of significance during 5 years study period. It is thus concluded that profitability and management efficiency are significantly positively correlated.

\section{Conclusion}

In refining; India is rising as a potential hub because of lower capital costs as compared to other Asian nations. According to one report by Deutsche Bank, India ranks fifth in the category of refining. Its share is $3 \%$ of the capacity worldwide and is going to improve further by $45 \%$ over the next 5 years. The automobile industry is poised to grow to 20 million by 2030 . This makes India the 3rd-largest market for automobiles worldwide. Thus, the need for more petroleum and petroleumbased products is going to rise further. The Indian chemicals industry has a diversified manufacturing base that produces world-class products. There is a 
substantial presence of downstream industries in all segments. Further, this large and expanding domestic chemicals market also boasts of a large pool of highly-trained scientific manpower. The particular research is of high importance to reflect the efficiency of the petrochemical industries that would lead to the growth of oil sectors.

\section{References}

[1] Eljelly A 2004 Liquidity-profitability tradeoff: an empirical investigation in an emerging market. Int. J.Commerce \& Manage. 14, 48-61.

[2] Eskandari J (2007) Accounting principles. Tehran Sazeman Publ.

[3] Garcia-Teruel, J.P., \& Martinez-Solano, P. (2007). Effects of working capital management on SME profitability.International Journal of Managerial Finance, 3(2), 164-177.

[4] Kothari CR (2008) Research Methodology. New AGE Int. Publ., New Delhi.
[5] Kaen Fred,R and Baumann Hans (2003). "Firm Size, Employees and Profitability in US Manufacturing Industries”, hhtp:// ssrn.com/sol.papers.

[6] Manor Selvi, A. and Vijayakumar, A. (2007). "Structure of profit rates in Indian Automobile Industries - A comparision", The Management Accountant,42(10) : 784-789.

[7] Patel, D.M.(2004). "Proft and Profitability (A case study of Colour-Chem Limited)", ACCST Research Journal, II(2) : 89-95.

[8] Parikh, H. M. (2012). Financial restructuring and its impact on corporate performance in India.(Doctoral Thesis), Gujarat University, Gujrat.

[9] Patel, D.M.(2004). "Proft and Profitability (A case study of Colour-Chem Limited)", ACCST Research Journal, II(2) : 89-95.

[10] Vijayakumar, A and Kadirvelu,S.(2004). "Determinants of Profitability: The case study of Indian Public Sector Power Industries", The Management Acountant, 39(2) : 118-123 